\title{
EFFECT OF SUPPLEMENTING TMR DIETS WITH ARTIFICIAL SALIVA AND ACID BUF ON OPTIMIZING RUMINAL PH AND FERMENTATION ACTIVITY IN COWS*
}

\author{
Krzysztof Bilik, Juliusz Strzetelski, Iwona Furgał-Dierżuk, Bogdan Śliwiński
}

\author{
Department of Animal Nutrition and Feed Science, National Research Institute of Animal Production, \\ 32-083 Balice n. Kraków, Poland \\ •Corresponding author: krzysztof.bilik@izoo.krakow.pl
}

\begin{abstract}
The objective of the study was to determine the effect of adding buffering agents to a total mixed ration (TMR) on the $\mathrm{pH}$ and on the VFA, lactic acid and $\mathrm{NH}_{3}-\mathrm{N}$ content of rumen fluid. The experiment was carried out with three nonproductive cows fitted with permanent rumen fistulas in a $3 \times 3$ Latin square design with two stages differing in the amount of added buffer (50 g/day in stage I or $100 \mathrm{~g} /$ day in stage II). The control diet (C) contained no buffering agent. The AB experimental diet was supplemented with Acid Buf (Noack Polen Ltd.) containing calcium carbonate, major and trace elements, and the AS experimental diet was supplemented with our own produced artificial saliva powder containing a mixture of chemical compounds $\left(\mathrm{NaHCO}_{3}, \mathrm{KCl}\right.$, $\mathrm{CaCl}_{2}, \mathrm{Na}_{2} \mathrm{HO}_{4} \cdot 12 \mathrm{H}_{2} \mathrm{O}, \mathrm{NaCl}, \mathrm{MgSO}_{4} \cdot 7 \mathrm{H}_{2} \mathrm{O}$ ) in the appropriate proportions (McDougall, 1948), combined with wheat bran at a 1:1 ratio. The preparations were added to the concentrate mixture in TMR which contained (\% DM): maize silage, 29.9; wilted grass silage, 17.4; ensiled brewers' grains, 2.4; barley straw, 10.3; and concentrate mixture, 40.0. Samples of rumen fluid collected before feeding $(0 \mathrm{~h})$ and after feeding $(2,4,6$ and $8 \mathrm{~h})$ were analysed for $\mathrm{pH}$, and the samples collected $4 \mathrm{~h}$ postprandial were analysed for $\mathrm{VFA}$, lactic acid and $\mathrm{NH}_{3}-\mathrm{N}$. The artificial saliva added at $100 \mathrm{~g} / \mathrm{day}$ to the mixture of chemical compounds (without a carrier) contributed to a significant $(\mathrm{P} \leq \mathbf{0 . 0 1})$ increase in rumen fluid $\mathrm{pH}$ at $4 \mathrm{~h}$ compared to cows receiving diets $\mathrm{C}$ and $\mathrm{AB}$. In both stages of the experiment, cows receiving the buffering agents tended to achieve higher $\mathrm{pH}$ values in the other hours of the test compared to group $\mathrm{C}$. In the collected samples of rumen fluid, no significant $(\mathrm{P}>0.05)$ differences were observed among the cows in VFA and total VFA, in C2/C3 and $\mathrm{C} 3 / \mathrm{C} 4$ acid ratios, and in $\mathrm{NH}_{3}-\mathrm{N}$ content. Neither did the type and amount of buffers had a significant effect on the percentage ratios of selected fatty acids (acetic, propionic and butyric) in total VFA. No presence of lactic acid was detected in the analysed samples of rumen fluid. It can be stated that when the total mixed ration is properly balanced, the type and amount of buffers have no significant effect on changes in the rumen fermentation activity of cows.
\end{abstract}

Key words: cows, TMR, artificial saliva, Acid Buf, rumen fluid, pH, fermentation activity

*This work was financed by Multi-annual Programme no. 05-001.9. 
The normal physiological $\mathrm{pH}$ of rumen contents, which provides the optimum environment for microorganisms, ranges from 6.0 to 7.2 (Krause and Oetzel, 2006; Jouany, 2006). It is regulated principally by saliva, the daily production of which is approx. 140-160 1 and depends on the type of ingested feed (Bailey, 1966). The main components of saliva are $\mathrm{Na}^{+}, \mathrm{K}^{+}, \mathrm{Cl}^{-}$and $\mathrm{HPO}_{4}^{2-}$ (Van Soest, 1994), and the high content of sodium carbonates and phosphates gives it an alkaline $\mathrm{pH}$ of approx. 8-8.6 (Richard, 1988). Recent studies (Adin et al., 2009; Yang and Beauchemin, 2009) have shown that with the increasing proportion of structural fibre (peNDF) in the rations, chewing time and saliva production are increased. However, this mechanism may be disturbed by feeding excessive concentrates to dairy cows (Morgante et al., 2007). What is more, the amount and buffering capacity of saliva produced by the modern dairy cow are insufficient to maintain rumen fluid $\mathrm{pH}$ at an optimal level (Marden et al., 2008). It would therefore be appropriate to use buffers, the composition and buffering properties of which are similar to those of cow's saliva (Lammers et al., 1996; Block and Sanchez, 2000; Krause and Oetzel, 2006). These include sodium bicarbonate, bentonite, ground limestone and sodium sesquicarbonate, which protect the rumen against low $\mathrm{pH}$ by neutralizing the acids formed during starch fermentation (Russell and Chow, 1993; Marden et al., 2008). Other ruminal buffers include alkalinizing agents (magnesium oxide, dolomite), but they neutralize rather than prevent excessive production of volatile fatty acids (Krause and Oetzel, 2006). In recent years, biological preparations (pro- and prebiotics) containing live and/ or dead microorganisms and their fermentation products are becoming increasingly popular (Bach et al., 2007; Denev et al., 2007; Oetzel et al., 2007). There is insufficient animal science literature on the possibility of using artificial saliva and Acid Buf, which contain biologically available minerals, as feed additives maintaining rumen fluid $\mathrm{pH}$ and fermentation activity at an optimal level.

The objective of the study was to determine the degree to which artificial saliva vs. feed additive (Acid Buf) will affect the $\mathrm{pH}$, and the VFA, lactic acid and $\mathrm{NH}_{3}-\mathrm{N}$ content of rumen fluid in cows fed a total mixed ration (TMR).

\section{Material and methods}

\section{Experimental design, diets, and management of cows}

The experiment was carried out with three nonproductive cows fitted with permanent rumen fistulas (ANKOM Products, Fairport, NY, USA) and individually fed a TMR diet containing (\% DM): maize silage, 29.9; wilted grass silage, 17.4; ensiled brewers' grains, 2.4; barley straw, 10.3; and concentrate mixture, 40.0. The study was performed in a $3 \times 3$ Latin square design with two stages differing in the amount of added buffer: $50 \mathrm{~g}$ /day in stage I or $100 \mathrm{~g}$ /day in stage II (Table 1). The control diet $(\mathrm{C})$ contained no buffering agent. The AB experimental diet was supplemented with Acid Buf (Noack Polen Ltd.) containing calcium carbonate, major and trace elements, and the AS experimental diet was supplemented with our own produced artificial saliva powder containing a mixture of chemical compounds $\left(\mathrm{NaHCO}_{3}\right.$, 
$\left.\mathrm{KCL}, \mathrm{CaCL}_{2}, \mathrm{Na}_{2} \mathrm{HO}_{4} \cdot 12 \mathrm{H}_{2} \mathrm{O}, \mathrm{NaCL}, \mathrm{MgSO}_{4} \cdot 7 \mathrm{H}_{2} \mathrm{O}\right)$ in the appropriate proportions (McDougall, 1948), combined with wheat bran at a 1:1 ratio.

Table 1. Experimental design

\begin{tabular}{l|c|ccc}
\hline Stage & $\begin{array}{c}\text { Additive } \\
\text { (g/day) }\end{array}$ & & Cows & \\
\hline I & C (0) & A & B & C \\
& AB (50) & B & C & A \\
& AS (50) & C & A & B \\
II & C (0) & A & B & C \\
& AB (100) & B & C & A \\
& AS (100) & C & A & B \\
\hline
\end{tabular}

${ }^{\mathrm{I}} \mathrm{C}$ - no additive; $\mathrm{AB}$ - Acid Buf; AS - artificial saliva. The amount of AS is a mixture of chemical compounds without a carrier.

The preparations were added to the concentrate mixture (in \%: ground maize, 33; ground triticale, 20; extracted soybean meal, 20; ground wheat, 13; rapeseed cake, 11; mineral mixture Dolfos, 3 ) in TMR formulated according to IZ PIB-INRA standards (2009) using INRAtion software (2006). The feed was offered once daily in the morning $(08: 00 \mathrm{~h})$, and mixed in the trough after $3-4 \mathrm{~h}$ to improve intake. Animals were housed in individual stalls covered with rubber mats (no straw bedding) and equipped with automatic drinkers and trough partitions.

The 86-day study consisted of a 14-day pretreatment period, in which animals were adjusted to the diet, and a 72-day treatment period, each having two 36-day stages. Each stage was subdivided into three 12-day periods consisting of a 7-day test period, in which animals were fed control diet (C) or experimental diets with additives (AB and $\mathrm{AS}$ ), and a 5-day transition period, in which animals were fed control diet alone.

\section{Measurements, chemical analyses and statistical calculations}

On day 7 of the experiment (test), liquid rumen contents were collected from each cow through a rumen fistula. Samples of rumen contents were collected five times: immediately before feeding $(0 \mathrm{~h})$ and 2, 4, 6 and $8 \mathrm{~h}$ after feeding. Immediately after collection, rumen contents were analysed for $\mathrm{pH}$ using an ELMETRON CP-411 $\mathrm{pH}$ meter with OSH 12-01 electrode. VFA, lactic acid and $\mathrm{NH}_{3}-\mathrm{N}$ were determined in fresh but stabilized rumen fluid samples collected $4 \mathrm{~h}$ after feeding. Metaphosphoric acid was used for VFA and lactic acid determination and magnesium oxide for $\mathrm{NH}_{3}-\mathrm{N}$. VFA analysis was performed using gas chromatography (Varian $3400 \mathrm{CX}$, column ZEBRON ZB-WAX 30m, 0.53 ID, 1.00 film thickness $(\mu \mathrm{m})$, program temp. $90-200^{\circ} \mathrm{C}$, analysis time $17 \mathrm{~min}$., injection temp. $200^{\circ} \mathrm{C}$, detector temp. $260^{\circ} \mathrm{C}$, range 11, helium as carrier gas, $6 \mathrm{ml} / \mathrm{min}$., injection volume $1 \mathrm{microl}$ ) with $8200 \mathrm{CX}$ autosampler. Lactic acid was determined by high-performance liquid chromatography (HPLC), following centrifugation of water filtrates with $24 \%$ metaphosphoric 
acid using a Shimadzu chromatograph (column LiChroCart, Superspher RP-18, 250 $\mathrm{mm}$ ). Ammonia was determined according to the method of Skulmowski (1974), whereby fresh samples were supplemented with magnesium oxide that displaced volatile nitrogenous bases from the solution during boiling, which were distilled into boric acid, and titrated with standard hydrochloric acid.

The basic chemical composition of the feeds was determined using standard procedures (AOAC, 2005), and NDF fractions in TMR according to Goering and Van Soest (1970) method. Feed intake by the cows was evaluated based on daily weighing of feed offered and the amount of feed refusals. The physical form of TMR was determined using the Penn State Particle Separator (PSPS) screens.

Statistical calculations of the results were made by three-way analysis of variance (mixed model) using the Mixed procedure in SAS software (2001). Significant differences between the groups were determined using Duncan's test. In the tables, values bearing different letters differ significantly, with capital letters denoting highly significant differences $(\mathrm{P} \leq 0.01)$ and no letters denoting non-significant differences $(\mathrm{P}>0.05)$.

\section{Results}

The chemical composition of feeds and the nutrient content of roughages and concentrates in TMR (Table 2) corresponded to the values characteristic of domestic feeds of medium or good quality (IZ PIB, 2010).

Table 2. Chemical composition (\% DM) of feeds in TMR

\begin{tabular}{l|c|c|c|c|c|c|c}
\hline \multirow{2}{*}{ Feeds } & \multirow{2}{*}{$\begin{array}{c}\text { Dry matter } \\
(\%)\end{array}$} & \multicolumn{1}{c}{$\begin{array}{c}\text { Ingredients } \\
\text { crude pro- } \\
\text { tein }\end{array}$} & $\begin{array}{c}\text { ether } \\
\text { extract }\end{array}$ & $\begin{array}{c}\text { crude } \\
\text { fibre }\end{array}$ & $\begin{array}{c}\text { N-free } \\
\text { extractives }\end{array}$ & $\begin{array}{c}\text { crude } \\
\text { ash }\end{array}$ & NDF \\
\hline Maize silage & 33.0 & 8.3 & 3.40 & 17.80 & 66.51 & 3.99 & 39.8 \\
Grass silage & 31.0 & 13.3 & 2.60 & 26.60 & 50.50 & 7.00 & 56.1 \\
Brewers' grains & 19.8 & 26.5 & 3.60 & 16.10 & 49.55 & 4.25 & 41.6 \\
Barley straw $_{\text {Concentrate mixture }}{ }^{1}$ & 86.0 & 4.26 & 2.04 & 43.78 & 44.36 & 5.56 & 72.6 \\
TMR $^{1}$ & 87.7 & 19.6 & 2.75 & 5.35 & 68.60 & 3.70 & - \\
\hline
\end{tabular}

${ }^{1}$ The composition of TMR and concentrate mixture is given in Material and methods. $1 \mathrm{~kg}$ DM of TMR contained approximately $0.89 \mathrm{UFL}, 101 \mathrm{~g}$ PDIN, $98 \mathrm{~g}$ PDIE. The respective values for concentrate mixture were 1.08 UFL, $149 \mathrm{~g}$ PDIN and $138 \mathrm{~g}$ PDIE. Percentage of TMR on sieves 1, 2 and 3 (physical form) averaged 12.5, 39.0 and 48.5 , respectively.

Regardless of the amount and type of the additive, the mean daily intake of feed by the cows during the experiment (Table 3$)$ was similar $(\mathrm{P}>0.05)$ and ranged from 25.9 to $26.3 \mathrm{~kg}$ TMR (11.4-11.6 kg DM).

The results for $\mathrm{pH}$ of cow rumen fluid depending on the type and amount of the additive are presented in Table 4. Artificial saliva (AS) added at $100 \mathrm{~g} / \mathrm{day}$ of the mixture of chemical compounds without a carrier (i.e. $200 \mathrm{~g} /$ day of additive) contributed to a significant $(\mathrm{P} \leq 0.01)$ increase in rumen fluid $\mathrm{pH}$ at $4 \mathrm{~h}$ of measurement, 
compared to the cows receiving the control diet $(\mathrm{C})$ or those supplemented with Acid Buf (AB). In both stages of the experiment, cows supplemented with AS or AB also showed a tendency for higher $\mathrm{pH}$ values in the other hours of the test, compared to cows fed the control diet (C). Regardless of the type and amount of buffering agents, the mean $\mathrm{pH}$ values of rumen fluid were highest (6.63-6.77) in samples collected immediately before feeding, and lowest (5.94-6.00) in samples collected at 4 and $6 \mathrm{~h}$ of measurement (Table 4).

Table 3. Mean daily intake of feed (TMR and DM) by the cows during the experiment

\begin{tabular}{l|l|c|c|c|c|c}
\hline \multirow{2}{*}{$\begin{array}{c}\text { Stage }-\begin{array}{c}\text { amount } \\
\text { of additive } \\
\text { (g/day) }\end{array} \\
\text { (g/dem }\end{array}$} & Item & $\begin{array}{c}\text { Fo additive } \\
(\mathrm{C})\end{array}$ & $\begin{array}{c}\text { with additive } \\
(\mathrm{AC})\end{array}$ & $\begin{array}{c}\text { with additive } \\
(\mathrm{AS})\end{array}$ & SEM & P \\
\cline { 3 - 6 } & TMR & 26.15 & 25.94 & 25.97 & 0.07 & 0.26 \\
$(50)$ & DM & 11.50 & 11.42 & 11.43 & 0.04 & 0.35 \\
II & TMR & 26.31 & 25.96 & 25.93 & 0.17 & 0.39 \\
$(100)$ & DM & 11.57 & 11.42 & 11.41 & 0.06 & 0.24 \\
\hline
\end{tabular}

Table 4. $\mathrm{pH}$ values of cow rumen fluid in different hours of measurement depending on the type and amount of additive

\begin{tabular}{l|c|c|c|c|c}
\hline \multirow{2}{*}{$\begin{array}{c}\text { Additive } \\
\text { (g/day) }\end{array}$} & \multicolumn{5}{c}{ Hour of measurement } \\
\cline { 2 - 6 } & 0 & 2 & 4 & 6 & 8 \\
\hline $\mathrm{C}(0)$ & 6.65 & 6.31 & 5.99 & 5.94 & 5.99 \\
$\mathrm{AB}(50)$ & 6.69 & 6.40 & 6.11 & 6.14 & 6.23 \\
$\mathrm{AS}(50)$ & 6.67 & 6.44 & 6.29 & 6.17 & 6.14 \\
SEM & 0.01 & 0.11 & 0.09 & 0.10 & 0.06 \\
$\mathrm{P}$ & 0.08 & 0.75 & 0.25 & 0.41 & 0.21 \\
$\mathrm{C}(0)$ & 6.65 & 6.30 & $6.03 \mathrm{~B}$ & 6.00 & 6.05 \\
AB (100) & 6.63 & 6.30 & $6.09 \mathrm{~B}$ & 6.06 & 6.18 \\
AS (100) & 6.77 & 6.39 & $6.30 \mathrm{~A}$ & 6.20 & 6.18 \\
SEM & 0.04 & 0.03 & 0.016 & 0.05 & 0.12 \\
$\mathrm{P}$ & 0.27 & 0.27 & 0.01 & 0.24 & 0.73 \\
\hline
\end{tabular}

${ }^{1}$ for artificial saliva, this means a mixture of compounds without a carrier.

The effect of the additives on the ruminal fermentation process is shown in Tables 5 and 6 . In the collected samples of rumen fluid, no significant $(\mathrm{P}>0.05)$ differences were observed between the cows in VFA and $\mathrm{NH}_{3}-\mathrm{N}$ content, acetic $(\mathrm{C} 2)$ to propionic acid $(\mathrm{C} 3)$ ratio, and propionic $(\mathrm{C} 3)$ to butyric acid $(\mathrm{C} 4)$ ratio.

The type and amount of buffering agents had no significant effect on total VFA and on percentage ratios of selected fatty acids (acetic, propionic and butyric) in total VFA in samples collected $4 \mathrm{~h}$ postprandial. No presence of lactic acid was detected in the analysed samples of rumen fluid. 
Table 5. Content of VFA, lactic acid and $\mathrm{NH}_{3}-\mathrm{N}$ and the ratio of some acids in the samples of cow ruminal fluid

\begin{tabular}{l|c|c|c|c|c|c|c|c|c|c}
\hline \multirow{2}{*}{$\begin{array}{c}\text { Additive } \\
(\mathrm{g} / \text { day })\end{array}$} & $\mathrm{C} 2$ & $\mathrm{C} 3$ & $\mathrm{C} 4$ & $\begin{array}{c}\text { Iso } \\
\mathrm{C} 4\end{array}$ & $\mathrm{C} 5$ & $\begin{array}{c}\text { Iso } \\
\mathrm{C} 5\end{array}$ & lactic & $\begin{array}{c}\mathrm{NH}_{3}-\mathrm{N} \\
(\mathrm{mg} / \mathrm{ml})\end{array}$ & $\begin{array}{c}\mathrm{C} 2 / \\
\mathrm{C} 3\end{array}$ & $\begin{array}{c}\mathrm{C} 3 / \\
\mathrm{C} 4\end{array}$ \\
\hline $\mathrm{C}(0)$ & 84.4 & 21.4 & 13.3 & 1.39 & 1.84 & 1.83 & 0.00 & 0.10 & 3.93 & 1.62 \\
$\mathrm{AB}(50)$ & 88.1 & 21.0 & 12.1 & 1.51 & 1.95 & 1.97 & 0.00 & 0.06 & 4.18 & 1.76 \\
$\mathrm{AS}(50)$ & 86.7 & 20.9 & 11.0 & 1.50 & 1.61 & 2.07 & 0.00 & 0.03 & 4.23 & 1.90 \\
$\mathrm{SEM}$ & 2.69 & 2.16 & 0.55 & 0.07 & 0.15 & 0.30 & - & 0.02 & 0.27 & 0.07 \\
$\mathrm{P}$ & 0.68 & 0.98 & 0.18 & 0.49 & 0.42 & 0.85 & - & 0.35 & 0.73 & 0.19 \\
$\mathrm{C}(0)$ & 81.9 & 19.6 & 10.4 & 1.38 & 2.22 & 1.73 & 0.00 & 0.01 & 4.21 & 1.86 \\
$\mathrm{AB}(100)$ & 82.4 & 20.6 & 11.3 & 1.46 & 1.74 & 1.92 & 0.00 & 0.01 & 4.07 & 1.80 \\
$\mathrm{AS}(100)$ & 79.4 & 18.7 & 10.3 & 1.36 & 1.85 & 1.71 & 0.00 & 0.02 & 4.26 & 1.84 \\
$\mathrm{SEM}$ & 0.86 & 2.07 & 0.73 & 0.02 & 0.21 & 0.15 & - & 0.01 & 0.17 & 0.12 \\
$\mathrm{P}$ & 0.22 & 0.82 & 0.65 & 0.16 & 0.42 & 0.62 & - & 0.74 & 0.75 & 0.94 \\
\hline
\end{tabular}

Table 6. Proportion (\%) of some acids in total VFA

\begin{tabular}{l|c|c|c|c}
\hline \multirow{2}{*}{$\begin{array}{c}\text { Additive } \\
(\mathrm{g} / \text { day })\end{array}$} & \multicolumn{4}{|c}{ Content of acids } \\
\cline { 2 - 5 } & $\begin{array}{c}\text { Total VFA } \\
(\mathrm{mmol} / \mathrm{l})\end{array}$ & $\begin{array}{c}\text { Acetic acid } \\
(\%)\end{array}$ & $\begin{array}{c}\text { Propionic acid } \\
(\%)\end{array}$ & $\begin{array}{c}\text { Butyric acid } \\
(\%)\end{array}$ \\
\hline $\mathrm{C}(0)$ & 124.2 & 67.9 & 17.2 & 10.7 \\
$\mathrm{AB}(50)$ & 126.6 & 69.6 & 16.6 & 9.8 \\
$\mathrm{AS}(50)$ & 123.8 & 70.0 & 16.8 & 8.9 \\
SEM & 2.03 & 1.35 & 0.82 & 0.48 \\
$\mathrm{P}$ & 0.64 & 0.53 & 0.85 & 0.17 \\
$\mathrm{C}(0)$ & 117.2 & 69.9 & 16.7 & 8.9 \\
AB (100) & 119.4 & 69.0 & 17.2 & 9.5 \\
AS (100) & 113.3 & 70.2 & 16.5 & 9.1 \\
SEM & 1.74 & 0.66 & 0.53 & 0.50 \\
P & 0.24 & 0.65 & 0.73 & 0.50 \\
\hline
\end{tabular}

\section{Discussion}

The results obtained in this physiological and feeding experiment involving cows fitted with permanent rumen fistulas point to a beneficial effect of the higher supplement (100 g/day of the mixture of chemical compounds without a carrier) of artificial saliva on elevating ruminal fluid $\mathrm{pH}$ at $4 \mathrm{~h}$ after feeding. Compared to artificial saliva, Acid Buf was less efficient in stabilizing the $\mathrm{pH}$ of ruminal contents in cows at all measurement hours. It should be stressed, however, that fluctuations in ruminal fluid $\mathrm{pH}$ of the experimental cows at different hours of measurement after feeding 
were within the physiologically normal range, providing optimum conditions for the rumen microorganisms (Krause and Oetzel, 2006; Jouany, 2006). This may suggest that the TMR was properly formulated in terms of structural fibre content (Adin et al., 2009; Yang and Beauchemin, 2009), which maintains the required physical form of the dairy cow ration (Osięgłowski and Strzetelski, 2002). The appropriate level of physically effective fibre (peNDF) in the rations has a considerable influence on the rumination process, the amount of saliva secreted (Owens et al., 1998; Maekawa et al., 2002) and digesta passage from the rumen to the lower parts of the digestive tract (Bailey, 1996; Al Zahal et al., 2009; Huhtanen et al., 2010; Martens et al., 2011). This is also confirmed by mostly non-significant differences in rumen fluid $\mathrm{pH}$ of cows supplemented with buffering agents, compared to animals fed the control diet, because an excess of easily fermentable carbohydrates in the ration could lead to excessively low $\mathrm{pH}$ of rumen fluid and the incidence of subclinical acidosis (Garrett et al., 1999; McLaughlin et al., 2009), which was not observed in the present experiment.

The positive results concerning the effect of feeding TMR diets to cows on stabilizing the $\mathrm{pH}$ of rumen contents are largely confirmed by the results obtained for its fermentation activity. The lack of lactic acid in rumen fluid sampled from the experimental cows and the non-significant differences in VFA and $\mathrm{NH}_{3}-\mathrm{N}$ content, in the acetic to propionic acid ratio $(\mathrm{C} 2 / \mathrm{C} 3)$, in the propionic to butyric acid ratio $(\mathrm{C} 3 / \mathrm{C} 4)$, and in the percentage of some acids in total VFA indicate that when the total mixed ration is properly balanced, the type and amount of buffers have no significant effect on changes in the rumen fermentation activity of these cows. This may also show that under the applied feeding conditions, the ruminal digestion and metabolism of structural carbohydrates were correct, and the supply of energy components and nitrogen compounds in the diet was appropriate (Oetzel et al., 1999). In the case where easily fermentable carbohydrates are oversupplied in the ration, this may impair the digestion of crude fibre and thus contribute to more intense propionic fermentation, expressed as the overly low level of acetic acid in total VFA and as shorter time of chewing the solid fraction of digesta. Similar results to ours with respect to the $\mathrm{pH}$ value, VFA content and total VFA in the rumen fluid of productive cows fed TMR diets with Acid Buf were also obtained by Cruywagen et al. (2004), Beya (2007), Cruywagen et al. (2007) and Calitz (2009). These authors reported that using 80-90 $\mathrm{g}$ of Acid Buf per day per cow in the first stage of lactation proved more effective in stabilizing rumen fluid $\mathrm{pH}$ compared to the commonly used sodium bicarbonate. Also other experiments with dairy cows receiving TMR diets supplemented with biological preparations containing live and/or dead microorganisms and the products of their fermentation (Bach et al., 2007; Denev et al., 2007; Oetzel et al., 2007) or fibrolytic enzymes (Bilik and Lopuszańska-Rusek, 2010) demonstrated their beneficial effects on stabilizing the population of rumen microorganisms and ruminal digestive activity. As suggested by some authors (Sutton et al., 2003), it can be assumed that the varying results obtained in different experiments for fermentative activity of the rumen in dairy cows could be due to environmental factors, in particular the type and method of feeding as well as the type of feed additives and physiological stage of the cow. 
In summary, we can say that when the total mixed ration is properly balanced, the type and amount of buffers have no significant effect on changes in the rumen fermentation activity of cows. The fluctuations in rumen fluid $\mathrm{pH}$ of the experimental cows at different hours of measurement after feeding were within the physiologically normal range, providing optimum conditions for the rumen microorganisms. The use of artificial saliva could be useful in pilot experiments testing the feeding efficiency of newly introduced buffers in complete rations for dairy cows.

\section{References}

Ad in G., Solomon R., Nikbachat M., Z en ou A., Yosef E., Brosh A., Shabtay A., M a b j e e s h S.J., H a la c h m i I., M i r o n J. (2009). Effect of feeding cows in early lactation with diets differing in roughage-neutral detergent fiber content on intake behavior, rumination, and milk production. J. Dairy Sci., 92: 3364-3373.

A 1 Zahal O., Or-Rashid M.M., Greenwood S.L., Douglas M.S., Mc Bride B.W. (2009). The effect of dietary fiber level on milk fat concentration and fatty acid profile of cows fed diets containing low levels of polyunsaturated fatty acids. J. Dairy Sci., 92: 1108-1116.

AOAC (2005). Association of Official Analytical Chemists. Official Methods of Analysis, Food Composition, Additives, Natural Contaminants, Arlington VA., 1: 684.

B a ch A., I g le sis a C., D e vant M. (2007). Daily rumen pH pattern of loose-housed dairy cattle as affected by feeding pattern and live yeast supplementation. Anim. Feed Sci. Technol., 136: $146-153$.

B a i l e y C.B. (1966). A note on the relationship between the rate of secretion of saliva and the rate of swallowing in cows at rest. Anim. Prod., 8: 325-328.

B e y a M.M. (2007). The effect of buffering dairy cow diets with limestone, Acid Buf or sodium bicarbonate on production response and rumen metabolism. MSc (Agric) thesis, University of Stellenbosch, South Africa.

Bilik K., Łopuszańska-Rusek M. (2010). Effect of adding fibrolytic enzymes to dairy cow rations on digestive activity in the rumen. Ann. Anim. Sci., 10: 127-137.

B 1 o ck E., S a n c h e z W.K. (2000). Is it important to adjust the dietary cation-anion difference for lactating dairy cows? Proc. Tri-State Dairy Nutrition Conference, Ohio State Cooperative Extension Service, Columbus, Ohio, pp. 27-39.

Calitz T. (2009). The effect of Acid Buf and combinations of Acid Buf and sodium bicarbonate in dairy cow diets on production response and rumen parameters. M. S. Thesis. Stellenbosch Univ., Matieland, South Africa, pp. 1-76.

Cruyw a ge n C.W., S w i e ger s J.P., T a y 1 or S.J., C o e tze e E. (2004). The effect of Acid Buf in dairy cow diets on production response and rumen parameters. J. Dairy Sci., 87 (Suppl.1), p. 46.

C ru y w a g e n C.W., Ta y l or S.J., B e y a M.M. (2007). The effect of buffering dairy cow diets with limestone, Acid Buf or sodium bicarbonate + limestone on production response and rumen parameters. J. Dairy Sci., 90 (Suppl. 1), p. 561.

D e nev S.A., P e eva T., R a du 1 ow a P., S t a n cheva N., S tay kova G., B e ev G., Todo rova P., Tc h ob a n ow a S. (2007). Yeast cultures in ruminant nutrition. Bulgarian J. Agric. Sci., 13: 357-374.

Garrett E.F., Pere ira M.N., Nordlund K.V., Armentano L.E., Goodger W.J., Oet z e 1 G.R. (1999). Diagnostic methods for the detection of subacute ruminal acidosis in dairy cows. J. Dairy Sci., 82: 1170-1178.

G o e ring H.K., Van S o e s t P.J. (1970). Forage Fiber Analyses. Agric. Handbook. Department of Agriculture, Washington, DC: p. 313.

Huhtanen P., A hvenjärvi S., B roderick G.A., Reynal S.M., Shing field K.J. (2010). Quantifying ruminal digestion of organic matter and neutral detergent fiber using the omasal sampling technique in cattle - a meta-analysis. J. Dairy Sci., 92: 3203-3215. 
IZ PIB (2010). Tabele składu chemicznego i wartość pokarmowa pasz krajowych. IZ PIB, Kraków, $100 \mathrm{pp}$.

J o u a n y J.P. (2006). Optimizing rumen functions in the close-up transition period and early lactation to drive dry matter intake and energy balance in cows. Anim. Reprod. Sci., 96: 250-64.

Krause K.M., Oetzel G.R. (2006). Understanding and preventing subacute ruminal acidosis in dairy herds: A review. Anim. Feed Sci. Tech., 126: 215-236.

L a m m e r s B.P., B u ckmaster D.R., Hi en rich s A.J. (1996). A simple method for the analysis of particle sizes of forage and total mixed rations. J. Dairy Sci., 79: 922-928.

Ma e kawa M., B e a u c h e m in K.A., Chris te n s en D.A. (2002). Effect of concentrate level and feeding management on chewing activities, saliva production, and ruminal $\mathrm{pH}$ of lactating dairy cows. J. Dairy Sci., 85: 1165-1175.

Marden J.P., Julien C., Monteils V., Auclair E., Moncoulon R., Bayourthe C. (2008). How does live yeast differ from sodium bicarbonate to stabilize ruminal $\mathrm{pH}$ in high-yielding dairy cows? J. Dairy Sci., 91: 3528-3535.

Martens H., R abban i I., Shen Z., S t u m ff E., D e in er C. (2011). Changes in rumen absorption processes during transition. Anim. Feed. Sci. Techn., 172: 95-102.

M c D o u ga 11 E. (1948). Studies on ruminal saliva. I. The composition and output of sheep's saliva. Biochem. J., 43: 99-109.

McLaughlin C.L., Thompson A., Greenwood K., Sherington J., Bruce C. (2009). Effect of acarbose on acute acidosis. J. Dairy Sci., 92: 2758-2766.

Morgante M., Stelletta C., B erzaghi P., Gianes ella M., Andighetto I. (2007). Subacute rumen acidosis in lactating cows: an investigation in intensive Italian dairy herds. J. Anim. Phys. Anim. Nutr., 91: 226-234.

O e t z e l G.R., N o r l un d K.V., G a r r e t t E.F. (1999). Effect of ruminal pH and stage of lactation on ruminal lactate concentrations in dairy cows. J. Dairy Sci., 82 (Suppl. 1), p. 38.

O e t z e 1 G.R., E m e r y K.M., K a u t z W.P., N o c e k J.E. (2007). Direct-fed microbial supplementation and health and performance of pre- and postpartum dairy cattle: A field trial. J. Dairy Sci., 90: 2058-2068.

Os i ęgłowski S., Strzetelski J. (2002). Current issues in the energy feeding of high-yielding cows during the dry perion (in Polish). Rocz. Nauk. Zoot., Supl., 15: 113-118.

O w e n s F.N., S e c r i s t D.S., H i 11 W.J., G i 11 D.R. (1998). Monensin and abomasal protein passage of steers. J. Anim. Sci., 76: 275-286.

R i chard A.E. (1988). Dietary buffering requirements of the lactating dairy cow: A review. J. Dairy Sci., 71: 3246-3266.

Rus s e 11 J.B., Chow J.M. (1993). Another theory for the action of ruminal buffer salts: Decreased starch fermentation and propionate production. J. Dairy Sci., 76: 826-830.

Skulmowski J. (1974). Metody określania składu pasz i ich jakości. PWRiL, Warszawa, pp. 79-82.

Sutton J.D., Phip ps R.H., B e ever D.E., Humphries D.J., Hartnell G.F., Vic in i J.L., H a rd D.L. (2003). Effect of method of application of a fibrolytic enzyme product on digestive processes and milk production in Holstein-Friesian cows. J. Dairy Sci., 86: 546-556.

Van S o e s t P.J. (1994). Nutritional Ecology of the Ruminant. New York, Cornell University Press.

Yang W.Z., B e a u c h e m in K.A. (2009). Increasing physically effective fiber content of dairy cow diets through forage proportion versus forage chop length: Chewing and ruminal pH. J. Dairy Sci., 92: $1603-1615$.

Received: 6 XI 2013

Accepted: 11 IV 2014 